\title{
Comparison of the Adsorption of Several Drugs to Typical Filter Materials
}

\author{
Marc Lindenberg ${ }^{1}$, Cornelia Wiegand ${ }^{2}$, Jennifer B. Dressman ${ }^{1,3}$
}

email:Dressman@em.uni-frankfurt.de

\section{Introduction}

Most current dissolution procedures require samples to be withdrawn from the vessel, the exception being when the concentration is determined in situ with fiber optics. No matter whether the sample is withdrawn manually or automatically, effective filters are necessary to prepare the sample for analysis; otherwise, undissolved material from the medium could influence the results. All of the filter materials available on the market for dissolution testing may not be equally suitable for this task. For example, it is important that filter materials should have little or no tendency to adsorb the drug, since adsorption to the filter will result in out-of-specification results.

The aim of this study was to examine drug adsorption to typical filter materials under a variety of dissolution test conditions. In addition, the influence of discarding the first 2 $\mathrm{ml}$ of the sample on adsorption to the filter was examined. Four different filter materials (nylon, cellulose acetate, regenerated cellulose and glass fiber) were tested with three model drugs: hydrochlorothiazide (highly water soluble), griseofulvin (poorly water soluble) and propranolol hydrochloride (cationic, highly water soluble) under various conditions. These conditions consisted of three dissolution media commonly used in USP dissolution testing and covered a $\mathrm{pH}$ range from $\mathrm{pH} 1.2$ to $\mathrm{pH} 6.8$.

\section{Materials and Methods \\ Materials}

Hydrochlorothiazide (lot 122K1567), griseofulvin (lot 043K1396) and propranolol hydrochloride (lot S09109-453) were purchased from Sigma Aldrich, USA. All chemicals were analytical grade and purchased commercially.

A total of five different filters were examined. The filters were kindly provided by Schleicher \& Schuell MicroScience GmbH (Dassel, Germany). The details of the filters can be found in Table 1.

\section{Media}

The media used for the experiments were Simulated Gastric Fluid pH 1.2 (SGF), deionized water and Simulated Intestinal Fluid pH 6.8 (SIF). The composition of the buffers is described in the USP [1]. Standard solutions of the three drugs were prepared in each of the media. The concentrations of the drugs in the standard solutions are given in Table 2.
In order to attain the required concentration in the media, ethanol (3\%) was added to the griseofulvin solutions.

To analyze the amount of drug adsorbed to the filter materials, the recovery of the drug in the filtered solution was determined. For each $\mathrm{drug} /$ medium combination, six samples of stock solution were withdrawn with a glass syringe (Fortuna ${ }^{\circledR}$ Optima ${ }^{\circledR}$ Luer Lock, Wertheim, Germany), and filtered immediately. The concentration of the drug in the filtrate was measured via UV spectroscopy. For each sample a new filter was used.

As a reference, six samples were withdrawn directly with the glass syringe (no filter) from the stock solution and the drug concentration measured by UV spectroscopy at the same wavelength.

The values obtained with and without filtration were then compared and results reported as \% recovery according to the following formula:

$$
\% \text { Recovery }=\frac{A_{s p l}}{A_{s t d}} * 100
$$

$A_{s p l}=$ value of the filtered solution

$A_{\text {std }}=$ value of the unfiltered solution
Table 1: Filters used in the experiment

\begin{tabular}{|lcc|}
\hline Product name & Material & Mesh width \\
\hline Roby 25/ GF 92 & Glass fiber & $1.0 \mu \mathrm{m}$ \\
\hline Roby 25/ GF 55 & Glass fiber & $0.7 \mu \mathrm{m}$ \\
\hline Roby 25/0.45 $\mathrm{RC}^{\circledast}$ & Regenerated cellulose membrane & $0.45 \mu \mathrm{m}$ \\
\hline Roby 25/0.45 $\mathrm{CA}^{\oplus}$ & Cellulose acetate membrane & $0.45 \mu \mathrm{m}$ \\
\hline Roby 25/0.45 NL & Polyamide/Nylon membrane & $0.45 \mu \mathrm{m}$ \\
\hline
\end{tabular}

Table 2: Concentrations of the drugs in the different media

\begin{tabular}{|lccc|}
\hline & $\begin{array}{c}\text { Simulated } \\
\text { Gastric Fluid } \\
\text { (pH 1.2) }\end{array}$ & $\begin{array}{c}\text { Deionized } \\
\text { water }\end{array}$ & $\begin{array}{c}\text { Simulated } \\
\text { Intestinal Fluid } \\
\text { (pH 6.8) }\end{array}$ \\
\hline Griseofulvin & $8.52 \mathrm{mg} / \mathrm{L}$ & $8 \mathrm{mg} / \mathrm{L}$ & $8.72 \mathrm{mg} / \mathrm{L}$ \\
\hline Hydrochlorothiazide & $6.66 \mathrm{mg} / \mathrm{L}$ & $6.66 \mathrm{mg} / \mathrm{L}$ & $7.29 \mathrm{mg} / \mathrm{L}$ \\
\hline Propranolol hydrochloride & $25.8 \mathrm{mg} / \mathrm{L}$ & $26.2 \mathrm{mg} / \mathrm{L}$ & $26.32 \mathrm{mg} / \mathrm{L}$ \\
\hline
\end{tabular}

${ }^{1}$ Department of Pharmaceutical Technology, J. W. Goethe University, Marie-

Curie Str. 9, 60439 Frankfurt am Main, Germany
${ }^{2}$ Schleicher \& Schuell MicroScience GmbH, Hahnestr. 3, 37586 Dassel, Germany

${ }^{3}$ To whom correspondence should be addressed. 
Nylon (Roby 25/0.45 NL)

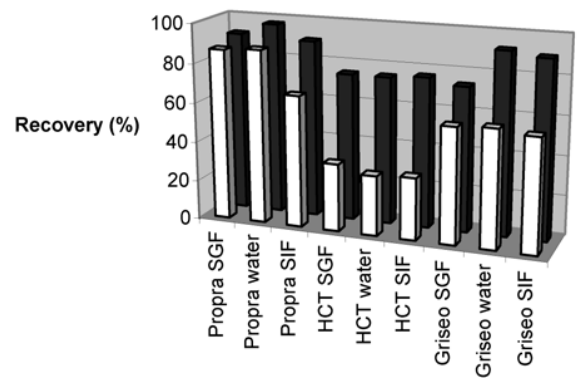

Figure 1. Recovery in \% for the nylon (Roby $25 / 0.45 N{ }^{\circledR}$ ) filters.
Cellulose acetate (Roby 25/0.45 CA)

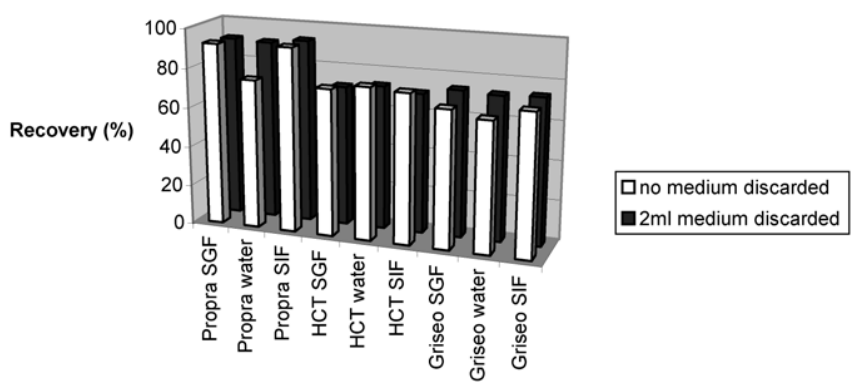

Figure 2. Recovery in \% for the cellulose acetate (Roby 25/0.45 CA ${ }^{\circledR}$ ) filters.

Table 3: Recovery in \% for the nylon (Roby 25/0.45 NL ${ }^{\circledR}$ ) filters

\begin{tabular}{|lccccccccc|}
\hline $\begin{array}{l}\text { no medium } \\
\text { discarded }\end{array}$ & $\begin{array}{l}\text { HCT } \\
\text { SGF }\end{array}$ & $\begin{array}{c}\text { HCT } \\
\text { water }\end{array}$ & $\begin{array}{c}\text { HCT } \\
\text { SIF }\end{array}$ & $\begin{array}{c}\text { Griseofulvin } \\
\text { SGF }\end{array}$ & $\begin{array}{c}\text { Griseofulvin } \\
\text { water }\end{array}$ & $\begin{array}{c}\text { Griseofulvin } \\
\text { SIF }\end{array}$ & $\begin{array}{c}\text { Propranolol } \\
\text { SGF }\end{array}$ & $\begin{array}{c}\text { Propranolol } \\
\text { water }\end{array}$ & $\begin{array}{c}\text { Propranolol } \\
\text { SIF }\end{array}$ \\
\hline mean & 34.2 & 30.3 & 31.5 & 58.6 & 59.6 & 57.5 & 88.0 & 86.9 \\
\hline standard deviation & 2.9 & 3.9 & 4.7 & 2.0 & 2.5 & 1.6 & 2.9 & 1.4 \\
\hline $\begin{array}{l}\mathbf{2} \text { ml medium } \\
\text { discarded }\end{array}$ & & & & & & & & & \\
\hline mean & 74.8 & 74.8 & 76.3 & 73.3 & 92.2 & 90.0 & 97.3 & 91.3 \\
\hline standard deviation & 1.8 & 2.8 & 2.9 & 2.0 & 2.0 & 1.9 & 2.1 & 90.0 \\
\hline
\end{tabular}

Table 4: Recovery in \% for the cellulose acetate (Roby 25/0.45 CA ${ }^{\circledR}$ ) filters

\begin{tabular}{|lccccccccc|}
\hline $\begin{array}{l}\text { no medium } \\
\text { discarded }\end{array}$ & $\begin{array}{l}\text { HCT } \\
\text { SGF }\end{array}$ & $\begin{array}{c}\text { HCT } \\
\text { water }\end{array}$ & $\begin{array}{c}\text { HCT } \\
\text { SIF }\end{array}$ & $\begin{array}{c}\text { Griseofulvin } \\
\text { SGF }\end{array}$ & $\begin{array}{c}\text { Griseofulvin } \\
\text { water }\end{array}$ & $\begin{array}{c}\text { Griseofulvin } \\
\text { SIF }\end{array}$ & $\begin{array}{c}\text { Propranolol } \\
\text { SGF }\end{array}$ & $\begin{array}{c}\text { Propranolol } \\
\text { water }\end{array}$ & $\begin{array}{c}\text { Propranolol } \\
\text { SIF }\end{array}$ \\
\hline mean & 74.1 & 76.7 & 75.4 & 69.3 & 65.8 & 71.6 & 92.2 & 75.3 \\
\hline standard deviation & 3.7 & 3.4 & 4.7 & 2.2 & 3.6 & 3.6 & 2.0 & 4.0 & 3.7 \\
\hline $\begin{array}{l}\mathbf{2} \text { ml medium } \\
\text { discarded }\end{array}$ & & & & & & & & & \\
\hline mean & 70.9 & 72.8 & 71.0 & 74.0 & 72.9 & 73.7 & 91.3 & 90.5 \\
\hline standard deviation & 1.5 & 0.7 & 4.0 & 3.0 & 1.9 & 2.3 & 1.6 & 0.7 \\
\hline
\end{tabular}

To examine the influence of discarding the first $2 \mathrm{ml}$ of the sample on adsorption, a second study was performed under identical conditions, with the exception that the first $2 \mathrm{ml}$ of the filtrate were discarded and an aliquot of the remaining filtrate was measured via UV spectroscopy.

All results are reported as mean \pm standard deviation, with recovery of $\geq 95 \%$ as the criterion for acceptable adsorption.

\section{UV Analysis}

The UV system used was a Hitachi U-3000 spectrophotometer (Tokyo, Japan). The program used for the analysis was UV Solutions 1.2. Griseofulvin was detected at a wavelength of $291 \mathrm{~nm}$; hydrochlorothiazide (HCT) at a wavelength of $272 \mathrm{~nm}$, and propranolol hydrochloride was detected at $289 \mathrm{~nm}$. The wavelength was kept constant in all buffers.

Results

Recovery of the Drugs

The results for the nylon (Roby $25 / 0.45 \mathrm{NL}^{\circledR}$ ) filters are shown in Figure 1 and Table 3.

Figure 1 shows the percentage recovery after filtration 
Regenerated cellulose (Roby 25/0.45 RC)

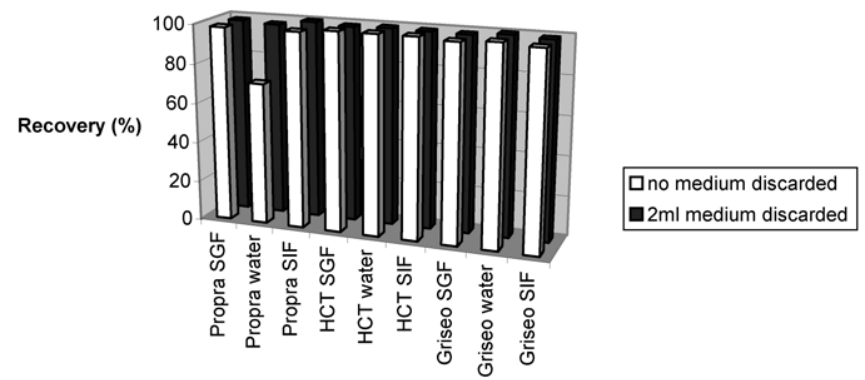

Figure 3. Recovery in \% for the regenerated cellulose (Roby $25 / 0.45 R C^{\circledR}$ ) filters.
Glass fiber (Roby 25/GF 55)

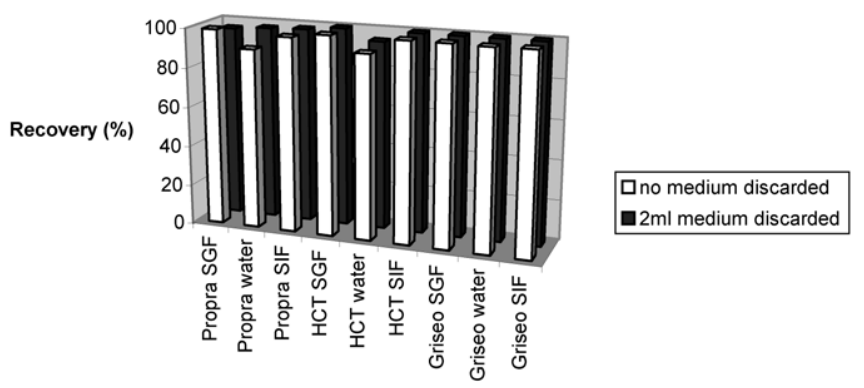

Figure 4. Recovery in \% for the glass fiber (Roby $25 /$ GF $55^{\circledR}$ ) filters.

Table 5: Recovery in \% for the regenerated cellulose (Roby 25/0.45 RC ${ }^{\circledR}$ ) filters

\begin{tabular}{|lccccccccc|}
\hline $\begin{array}{l}\text { no medium } \\
\text { discarded }\end{array}$ & $\begin{array}{c}\text { HCT } \\
\text { SGF }\end{array}$ & $\begin{array}{c}\text { HCT } \\
\text { water }\end{array}$ & $\begin{array}{c}\text { HCT } \\
\text { SIF }\end{array}$ & $\begin{array}{c}\text { Griseofulvin } \\
\text { SGF }\end{array}$ & $\begin{array}{c}\text { Griseofulvin } \\
\text { water }\end{array}$ & $\begin{array}{c}\text { Griseofulvin } \\
\text { SIF }\end{array}$ & $\begin{array}{c}\text { Propranolol } \\
\text { SGF }\end{array}$ & $\begin{array}{c}\text { Propranolol } \\
\text { water }\end{array}$ & $\begin{array}{c}\text { Propranolol } \\
\text { SIF }\end{array}$ \\
\hline mean & 104 & 103 & 103 & 98.9 & 100.9 & 98.9 & 98.3 & 71.3 \\
\hline standard deviation & 3.4 & 2.2 & 2.0 & 1.9 & 1.5 & 1.9 & 2.7 & 2.0 & 2.4 \\
\hline $\begin{array}{l}\mathbf{2} \text { ml medium } \\
\text { discarded }\end{array}$ & & & & & & & & & \\
\hline mean & 98.8 & 99.3 & 99.0 & 98.7 & 101 & 99.0 & 98.4 & 97.4 \\
\hline standard deviation & 2.4 & 3.5 & 2.2 & 1.7 & 2.7 & 2.3 & 1.5 & 100 \\
\hline
\end{tabular}

Table 6: Recovery in \% for the glass fiber (Roby 25/GF 55 ${ }^{\circledR}$ ) filters

\begin{tabular}{|lccccccccc|}
\hline $\begin{array}{l}\text { no medium } \\
\text { discarded }\end{array}$ & $\begin{array}{l}\text { HCT } \\
\text { SGF }\end{array}$ & $\begin{array}{c}\text { HCT } \\
\text { water }\end{array}$ & $\begin{array}{c}\text { HCT } \\
\text { SIF }\end{array}$ & $\begin{array}{c}\text { Griseofulvin } \\
\text { SGF }\end{array}$ & $\begin{array}{c}\text { Griseofulvin } \\
\text { water }\end{array}$ & $\begin{array}{c}\text { Griseofulvin } \\
\text { SIF }\end{array}$ & $\begin{array}{c}\text { Propranolol } \\
\text { SGF }\end{array}$ & $\begin{array}{c}\text { Propranolol } \\
\text { water }\end{array}$ & $\begin{array}{c}\text { Propranolol } \\
\text { SIF }\end{array}$ \\
\hline mean & 105 & 92.5 & 107 & 100 & 99.6 & 99.9 & 99.2 & 90.6 \\
\hline standard deviation & 4.1 & 1.7 & 3.5 & 1.5 & 2.3 & 0.8 & 1.1 & 2.6 & \\
\hline $\begin{array}{l}\mathbf{2} \text { ml medium } \\
\text { discarded }\end{array}$ & & & & & & & & & \\
\hline mean & 101 & 94.7 & 102 & 100 & 101 & 100 & 96.4 & 97.6 \\
\hline standard deviation & 2.2 & 1.5 & 3.4 & 1.6 & 1.5 & 1.4 & 2.3 & 0.3 \\
\hline
\end{tabular}

through the nylon filter, with and without discarding the first $2 \mathrm{ml}$ of the filtered solution.

The nylon filters did not show acceptable results for any of the drug/medium combinations. The recovery of the drugs varied from $30 \%$ (HCT in water) to $88 \%$ (propranolol hydrochloride in SGF pH 1.2) when no filtrate was discarded prior to collection for analysis. These values are too low to warrant the use of nylon filters in dissolution tests.

When $2 \mathrm{ml}$ of medium were discarded prior to collecting sample for analysis the values improved, especially for hydrochlorothiazide, but they were still not satisfactory; only propranolol hydrochloride in SGF had a recovery higher than $95 \%$.
The results for the cellulose acetate (Roby $25 / 0.45 \mathrm{CA}^{\oplus}$ ) filters are shown in Figure 2 and Table 4.

The recovery of both griseofulvin and hydrochlorothiazide after filtration through cellulose acetate filters was well below $80 \%$, with or without discarding $2 \mathrm{ml}$.

For cellulose acetate filters, discarding the first $2 \mathrm{ml}$ of medium prior to sample analysis showed little effect, except for the combination propranolol hydrochloride/water.

Although some of the propranolol recovery rates were above $90 \%$, the $95 \%$ mark could not be achieved in any medium for this drug.

The results for the regenerated cellulose (Roby 25/0.45 $R C^{\oplus}$ ) filters are shown in Figure 3 and Table 5. 
Table 7: Recovery in \% for the glass fiber (Roby 25/GF 92 ${ }^{\circledR}$ )

\begin{tabular}{|c|c|c|c|c|c|c|c|c|c|}
\hline $\begin{array}{l}\text { no medium } \\
\text { discarded }\end{array}$ & $\begin{array}{l}\mathrm{HCT} \\
\mathrm{SGF}\end{array}$ & $\begin{array}{l}\mathrm{HCT} \\
\text { water }\end{array}$ & $\begin{array}{l}\mathrm{HCT} \\
\mathrm{SIF}\end{array}$ & $\begin{array}{c}\text { Griseofulvin } \\
\text { SGF }\end{array}$ & $\begin{array}{c}\text { Griseofulvin } \\
\text { water }\end{array}$ & $\begin{array}{c}\text { Griseofulvin } \\
\text { SIF }\end{array}$ & $\begin{array}{c}\text { Propranolol } \\
\text { SGF }\end{array}$ & $\begin{array}{c}\text { Propranolol } \\
\text { water }\end{array}$ & $\begin{array}{c}\text { Propranolol } \\
\text { SIF }\end{array}$ \\
\hline mean & 105 & 103 & 101 & 95.6 & 95.5 & 95.2 & 99.6 & 90.5 & 96.7 \\
\hline standard deviation & 3.7 & 1.5 & 1.5 & 1.5 & 2.1 & 1.7 & 1.1 & 3.5 & 2.3 \\
\hline \multicolumn{10}{|l|}{$\begin{array}{l}2 \mathrm{ml} \text { medium } \\
\text { discarded }\end{array}$} \\
\hline mean & 101 & 99.9 & 101 & 100 & 99.7 & 99.5 & 98.2 & 99.4 & 97.7 \\
\hline standard deviation & 2.5 & 1.1 & 1.6 & 2.3 & 1.5 & 0.9 & 1.2 & 2.2 & 1.5 \\
\hline
\end{tabular}

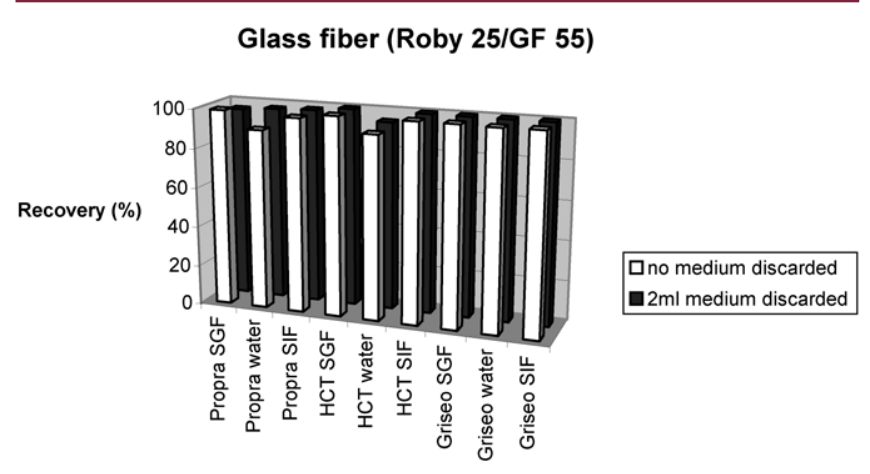

Figure 5. Recovery in \% for the glass fiber (Roby 25/GF 92 ${ }^{\circledR}$ ) filters

The recovery of all three drugs was greater than $95 \%$ when $2 \mathrm{ml}$ were discarded prior to analysis.

The discrepancy in the low recovery of propranolol in water in contrast to the other media with the regenerated cellulose filter could be a result of the positively charged propranolol ion interacting with the polar groups of the cellulose. This reaction is reduced in SGF and SIF because of the sodium and potassium ion content of these media, as described in the literature $[2,3]$.

The results for the glass fiber filters (Roby $25 / \mathrm{GF} 55^{\oplus}$ and Roby $25 /$ GF $92^{\circ}$ ) are shown in Figure $4+5$ and Tables $6+7$.

Filtration through the two glass fiber filters resulted in comparatively little loss of concentration.

At least $95 \%$ recovery could be achieved when $2 \mathrm{ml}$ of medium were discarded prior to analysis (except for $\mathrm{HCT} /$ water for the Roby $25 / \mathrm{GF} 55^{\circledR}$ ).

\section{Discussion}

The glass fiber and the regenerated cellulose filters showed good results with all drug/medium combinations. As the experiments cover a wide $\mathrm{pH}$ range, and the drugs examined have quite different properties, it is reasonable to assume that these filters would produce good results with a wide variety of drugs. However, the recovery of a drug should always be validated, because absence of specific interactions of the drug substance with the filter material can never be guaranteed. Discarding the first $2 \mathrm{ml}$ of medium had surprisingly little effect on recovery with these filters, except in the case of propranolol. Eliminating this step, if it can be shown not to improve the recovery, could save time when using the filters with manual sampling, and make automating the sampling procedure simpler.

A potential problem of clogging can occur with the glass fiber filters could arise with the pore size $(0.7-1.0 \mu \mathrm{m})$ when examining samples with very finely dispersed undissolved material. This would have to be evaluated during validation of the dissolution test.

The filters made of cellulose acetate and nylon did not perform well in this series of tests, therefore the use of other filters as first preference in dissolution testing is recommended. If cellulose acetate or nylon filters are used, discarding a volume of the sample prior to collection for analysis should improve the performance, but may prove impractical when using $5 \mathrm{ml}$ syringes.

\section{Acknowledgements}

Partial Support from Schleicher \& Schuell MicroScience $\mathrm{GmbH}$ is gratefully acknowledged.

\section{References}

1. United States Pharmacopeia and National Formulary, United States Pharmacopeial Convention Inc., Rockville, MD, USA, 26th Edition (2003)

2. O. Al-Gohary, J. Lyall, J.B. Murray, Adsorption of Anithypertensives by Suspenoids Part 1. The Adsorption of Propranolol Hydrochloride by Attapulgite, Charcoal, Kaolin and Magnesium Trisilicate, Pharm. Acta Helv. ,62, Nr. 3 (1987), 66-72

3. O. Al-Gohary, J. Lyall, J.B. Murray, The Effects of Varying Concentration and Valency, the Dielectric Constant and the Addition of Hydroxypropylmethylcellulose on the Adsorption of Propranolol Hydrochloride on to Magnesium Trisilicate, Pharm. Acta Helv. , 62, Nr. 10-11 (1987), 313-316 